Article

\title{
Experimental Design and Optimization of Triclosan and 2.8-Diclorodibenzeno-p-dioxina Degradation by the $\mathrm{Fe} / \mathrm{Nb}_{2} \mathrm{O}_{5} / \mathrm{UV}$ System
}

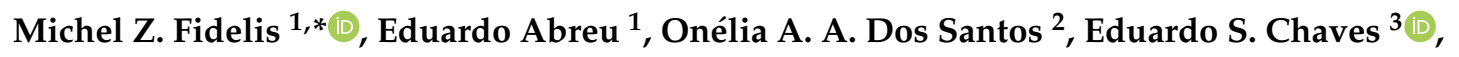 \\ Rodrigo Brackmann ${ }^{4}$, Daniele T. Dias ${ }^{5}$ and Giane G. Lenzi ${ }^{1}$ \\ 1 Departamento de Engenharia Química, Universidade Tecnológica Federal do Paraná, Av Monteiro Lobato, \\ s/n-Km 04, Ponta Grossa, PR 84016-210, Brazil; eduardo_abreu@live.com (E.A.); \\ gianeg@utfpr.edu.br (G.G.L.) \\ 2 Departamento de Engenharia Química, Universidade Estadual de Maringá, Avenida Colombo, 5790, \\ Maringá, PR 87020-900, Brazil; oaasantos@uem.br \\ 3 Departamento de Química, Universidade Federal de Santa Catarina, Campus Reitor João David Ferreira \\ Lima, R. Eng. Agronômico Andrei Cristian Ferreira, s/n, Florianópolis, SC 88040-900, Brazil; \\ eschaves@hotmail.com \\ 4 Departamento de Química, Universidade Tecnológica Federal do Paraná, Via do Conhecimento, \\ s/n-Km 01, Pato Branco, PR 85503-390, Brazil; rodrigobrackmann@utfpr.edu.br \\ 5 Departamento Acadêmico de Física, Universidade Tecnológica Federal do Paraná, Av Monteiro Lobato, \\ s/n-Km 04, Ponta Grossa, PR 84016-210, Brazil; danieletdias@utfpr.edu.br \\ * Correspondence: michelmzzf@gmail.com; Tel.: +55-42-3220-4800
}

Received: 11 February 2019; Accepted: 27 March 2019; Published: 8 April 2019

\begin{abstract}
This study describes the experimental design and optimization of the photocatalytic reaction using the immobilized catalyst $\mathrm{Fe} / \mathrm{Nb}_{2} \mathrm{O}_{5}$ in the degradation of Triclosan and 2.8-DCDD. The techniques employed to characterize the photocatalysts were: specific surface area, average pore volume, average pore diameter, photo-acoustic spectroscopy (PAS), X-ray diffraction (XRD), and scanning electron microscopy (SEM/EDS). The reaction parameters studied were $\mathrm{pH}$, catalyst concentration, catalyst calcination temperature, and nominal metallic charge. The results indicated that the immobilized $\mathrm{Fe} / \mathrm{Nb}_{2} \mathrm{O}_{5}$ catalysts were efficient in the degradation of Triclosan and 2.8-dichlorodibenzene-p-dioxin. The catalysts with nominal metal loading of $1.5 \%$ Fe calcined at $873 \mathrm{~K}$ showed the highest constant reaction rate and the lowest half-life $0.069 \mathrm{~min}^{-1}$ and $10.04 \mathrm{~min}$. Tests in different matrices indicated that the photocatalytic reaction using aqueous solution containing $\mathrm{Cl}^{-}$is faster when compared with the ultrapure water matrix.
\end{abstract}

Keywords: $\mathrm{Fe} / \mathrm{Nb}_{2} \mathrm{O}_{5}$ immobilized catalyst; emerging pollutants; degradation

\section{Introduction}

The chemical compounds progressive use, coupled with the low efficiency of effluent collection and treatment systems, have contributed to the significant increase in contaminants of emerging concern found in surface waters. This was considered to be of low risk to the environment, and these contaminants were detected only a few years ago.

Among the contaminants of emerging concern is the Triclosan (TCS) and 5-chloro-2-(2,4dichlorophenoxy)-5-phenol-an antimicrobial agent that is extensively used as a preservative in a variety of consumer products such as toothpaste, antiseptic soaps, detergents, cosmetics, plastic kitchenware, socks, rugs, and toys [1-3]. The TCS presence can be harmful to both human and animal health since it tends to undergo bio-magnification and can be degraded by photolysis, which 
generates by-products of greater toxicity, such as chlorophenols and dioxins [4-6]. Among the dioxins that may be formed, 2,8-dichlorodibenzene-p-dioxin (2.8-DCDD) stands out as being a chemically stable compound and it is known to suppress antibody responses. In addition, exposure to radiation, mainly in an environment with free chlorine, favors the reaction of transformation of the TCS in this compound [6,7].

Conventional water treatment methods are ineffective for removing substances with biological activity, such as Triclosan, and extremely stable substances such as dioxins. Therefore, in recent decades, Advanced Oxidation Processes (AOPs) have received attention as an alternative for removing these compounds. They are based on the hydroxyl radicals generation, which has a strong oxidizing character and has the capacity to degrade compounds through oxidation. The formation of free radicals that react with dissolved oxygen is an example of such [8,9].

Many semiconductors have been studied in the heterogeneous photo catalysis in order to degrade pollutants in water bodies $\left(\mathrm{ZnO}, \mathrm{CdO}, \mathrm{TiO}_{2}, \mathrm{Fe}_{2} \mathrm{O}_{3}\right.$, among others). Among these, $\mathrm{TiO}_{2}$ stands out as the most used photo catalyst due to its highly chemical stability, nontoxic, band gap of $3.2 \mathrm{eV}$ for UV radiation (natural/artificial), and relatively low cost [10-13]. However, since its band gap is $3.2 \mathrm{eV}$, the highest efficiency of the process is limited by the absorption of the $\mathrm{TiO}_{2}$ semiconductor with a radiation of over $385 \mathrm{~nm}$, which corresponds to approximately $3 \%$ of the solar spectrum at sea level.

Thus, the search for new catalysts becomes essential. The use of niobium pentoxide $\left(\mathrm{Nb}_{2} \mathrm{O}_{5}\right)$ as a semiconductor for application in heterogeneous photocatalysis has few literature references. This compound has chemical characteristics of low toxicity and band gap $(3.4 \mathrm{eV})$, which is very similar to $\mathrm{TiO}_{2}[14,15]$. It is a stable semiconductor and insoluble in water, which can be attacked only by concentrated hydrofluoric acid. Compared with vanadium oxide, it is more stable and difficult to reduce. In contrast to titanium oxide, it presents an advantage in some types of photo degradation [16].

Due to the characteristics of the oxide, it has been used in catalytic reactions such as dehydrogenation, alkylation, hydrolysis, and photocatalytic degradation. The study of $\mathrm{Nb}_{2} \mathrm{O}_{5}$ shows that it has a combination of energy when in contact with ultraviolet radiation, and, also, when together with another semiconductor, can greatly increase the catalytic activity and the life of a catalyst $[16,17]$.

One of the negative aspects of the photocatalytic process is the difficulty to separate the catalyst after its treatment. In this direction, the material immobilization allows the separation of the catalyst by avoiding the need of a later step in the process and increases the porosity, the adsorption capacity, and thermal stability [18]. On the other hand, a catalytic activity reduction occurs [19,20]. In order to improve the photoreaction efficiency, many authors have metals such as Ag [21], Fe [22], and Cu [23] added to it in order to prevent the process of electron/role recombination in semiconductors.

In this context, this study describes the optimization of the photocatalytic degradation of TCS and 2.8-DCDD using the immobilized $\mathrm{Fe} / \mathrm{Nb}_{2} \mathrm{O}_{5}$ as the photo-catalyst. It was also analyzed using different parameters such as $\mathrm{pH}$, catalyst concentration, and the catalyst calcination temperature.

\section{Results and Discussion}

\subsection{Catalysts Characterization}

\subsubsection{Pore Properties (BET Method)}

The results of the textural properties for the calcined $\mathrm{Fe} / \mathrm{Nb}_{2} \mathrm{O}_{5}$ catalysts at different temperatures are shown in Table 1.

A variation of the specific surface area for the studied catalysts ranges from 20.26 to $149.63 \mathrm{~m}^{2} \mathrm{~g}^{-1}$. The lowest area obtained for the samples was $0.5 \% \mathrm{Fe} / \mathrm{Nb}_{2} \mathrm{O}_{5}$ calcined at $673 \mathrm{~K}$, and the highest for the sample was $1.0 \% \mathrm{Fe} / \mathrm{Nb}_{2} \mathrm{O}_{5}$ at $773 \mathrm{~K}$. These results indicate the influence of the calcination temperature and the addition of $\mathrm{Fe}$. The $1.0 \% \mathrm{Fe} / \mathrm{Nb}_{2} \mathrm{O}_{5}$ catalysts and $0.5 \% \mathrm{Fe} / \mathrm{Nb}_{2} \mathrm{O}_{5}$ calcined at $773 \mathrm{~K}$ and $873 \mathrm{~K}$ practically obtained the same results of approximately $150 \mathrm{~m}^{2} \mathrm{~g}^{-1}$. The catalysts are mesoporous materials (pores of internal width between $20 \AA$ and $50 \AA$ ). When comparing the results of the pore diameter, it is possible to verify that the samples did not have significant 
variations in this property. Regarding the micro-pore volumes, there was considerable variation of $0.00518 \mathrm{~cm}^{3} \mathrm{~g}^{-1}\left(1.5 \% \mathrm{Fe} / \mathrm{Nb}_{2} \mathrm{O}_{5}\right.$ calcined at $\left.873 \mathrm{~K}\right)$ and $0.01064 \mathrm{~cm}^{3} \mathrm{~g}^{-1}\left(1.7 \% \mathrm{Fe} / \mathrm{Nb}_{2} \mathrm{O}_{5}\right.$ calcined at $773 \mathrm{~K}$ ). Fontana et al. (2018) [24] profiled a surface area of $1.50 \mathrm{~m}^{2} \mathrm{~g}^{-1}$, pore volume of $0.049 \mathrm{~cm}^{3} \mathrm{~g}^{-1}$, and pore diameter of $15.60 \AA$ for non-calcined $\mathrm{Nb}_{2} \mathrm{O}_{5}$ samples. Nakajima et al. (2011) [25] found that $\mathrm{Nb}_{2} \mathrm{O}_{5}$ samples calcined at $573 \mathrm{~K}$ had a pore volume of $0.21 \mathrm{~cm}^{3} \mathrm{~g}^{-1}$ and a diameter of $18 \AA$. When compared with the results obtained, it is noted that the surface areas of the immobilized $\mathrm{Fe} / \mathrm{Nb}_{2} \mathrm{O}_{5}$ catalysts are larger than those of the non-calcined and non-immobilized $\mathrm{Nb}_{2} \mathrm{O}_{5}$ catalysts, as well as their pore diameter.

Table 1. Summarizes the surface textural properties catalysts (Specific surface area (So), Micropore Volume $(\mathrm{Vm})$, and average pore diameter $(\mathrm{Dm})$.

\begin{tabular}{|c|c|c|c|}
\hline $\begin{array}{c}\text { Catalyst Fe/ } / \mathrm{Nb}_{2} \mathrm{O}_{5} \\
\text { wt \%-T Calcination (K) }\end{array}$ & So $\left(\mathrm{m}^{2} \mathrm{~g}^{-1}\right)$ & $\operatorname{Vm}\left(\mathrm{cm}^{3} \mathrm{~g}^{-1}\right)$ & $\operatorname{Dm}(\AA ̊)$ \\
\hline $0.3 \%-773$ & 49.51 & 0.00972 & 33.03 \\
\hline $0.5 \%-673$ & 20.26 & 0.00589 & 33.25 \\
\hline $0.5 \%-873$ & 148.83 & 0.00716 & 33.05 \\
\hline $1.0 \%-633$ & 29.55 & 0.00772 & 33.16 \\
\hline $1.0 \%-773$ & 149.63 & 0.00816 & 33.34 \\
\hline $1.0 \%-913$ & 25.42 & 0.00635 & 33.10 \\
\hline $1.5 \%-673$ & 64.90 & 0.00769 & 33.07 \\
\hline $1.5 \%-873$ & 21.24 & 0.00518 & 33.34 \\
\hline $1.7 \%-773$ & 43.44 & 0.01064 & 33.25 \\
\hline
\end{tabular}

\subsubsection{X-ray Diffraction (XRD)}

The XRD analysis of the calcined $\mathrm{Fe} / \mathrm{Nb}_{2} \mathrm{O}_{5}$ immobilized samples are presented in Figure 1. The peaks obtained were compared with the standards published by ICDD (International Center for Diffraction Data).

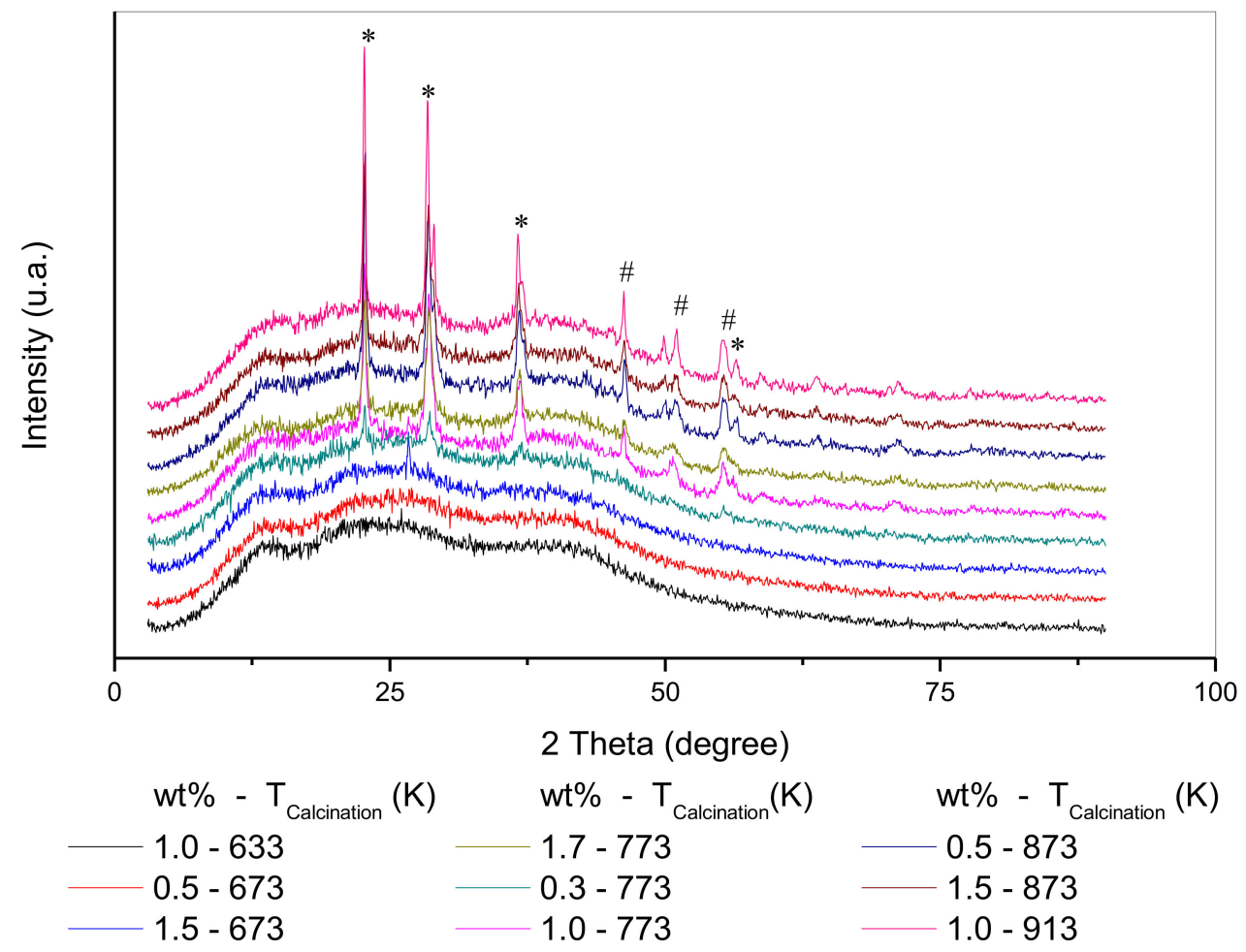

Figure 1. XRD pattern of $\mathrm{Fe} / \mathrm{Nb}_{2} \mathrm{O}_{5}$ sample where ${ }^{*}$ ) TT phase (pseudo-hexagonal form) (\#) T phase (orthorhombic form). 
By analyzing the diffractograms, it is possible to verify that the catalyst $1.0 \% \mathrm{Fe} / \mathrm{Nb}_{2} \mathrm{O}_{5}, 0.5 \%$ $\mathrm{Fe} / \mathrm{Nb}_{2} \mathrm{O}_{5}$, and $1.5 \% \mathrm{Fe} / \mathrm{Nb}_{2} \mathrm{O}_{5}$ samples calcined at $673 \mathrm{~K}$ have a non-crystalline (amorphous) structure. Similar results were found for niobium samples at the same catalyst calcination temperatures from research conducted by Morais et al. (2017) [26]. The diffractograms indicate that the $T T-\mathrm{Nb}_{2} \mathrm{O}_{5}$ (ICDD00-028-0317) with the cell parameters $\mathrm{a}=\mathrm{b}=3.6070 \AA, \mathrm{c}=3.9250 \AA$, and $T-\mathrm{Nb}_{2} \mathrm{O}_{5}$ (ICDD00-027-1313) forms with the cell parameters $\mathrm{a}=6.1680 \AA, \mathrm{b}=29.3120 \AA$, and $\mathrm{c}=3.9380 \AA$ were obtained for the catalysts calcined at temperatures higher than $673 \mathrm{~K}$. It was also observed that $1.0 \%$ $\mathrm{Fe} / \mathrm{Nb}_{2} \mathrm{O}_{5}, 1.7 \% \mathrm{Fe} / \mathrm{Nb}_{2} \mathrm{O}_{5}$ calcined at $773 \mathrm{~K}$ and $0.5 \% \mathrm{Fe} / \mathrm{Nb}_{2} \mathrm{O}_{5}, 1.5 \% \mathrm{Fe} / \mathrm{Nb}_{2} \mathrm{O}_{5}$ calcined at $873 \mathrm{~K}$ and $1.0 \% \mathrm{Fe} / \mathrm{Nb}_{2} \mathrm{O}_{5}$ calcined at $913 \mathrm{~K}$ showed a semi-crystalline structure, with crystallite sizes of $30,26,35,35$, and $40 \mathrm{~nm}$, respectively. The sample $0.3 \% \mathrm{Fe} / \mathrm{Nb}_{2} \mathrm{O}_{5} 773 \mathrm{~K}$ showed a semi-crystalline structure, but it was not possible to calculate the size of the crystallites and to determine a hexagonal shape due to it being very amorphous. Sreethawonget al. (2012) [27] found similar results for $\mathrm{Nb}_{2} \mathrm{O}_{5}$ sol-gel samples calcined at $773 \mathrm{~K}$ with an orthorhombic form (T) with crystallites of approximate size of $18.5 \mathrm{~nm}$. A result was also found by Liu et. al. (2011) [28] in $\mathrm{Nb}_{2} \mathrm{O}_{5}$ samples of an orthorhombic form $(\mathrm{T})$. However, the crystallite sizes were $0.39 \mathrm{~nm}$.

\subsubsection{Photoacoustic Spectroscopy (PAS)}

The band gap results and the absorption threshold for the $\mathrm{Nb}_{2} \mathrm{O}_{5}$ catalysts are shown in Table 2 . The values found ranged from 3.05 to $3.94 \mathrm{eV}$. According to Greenwood and Eranshaw (2003) [29], the band gap of $\mathrm{Nb}_{2} \mathrm{O}_{5}$ has a range of 3.1 to $4.0 \mathrm{eV}$. Analyzing the values obtained in relation to the nominal metallic load of $\mathrm{Fe}$, it was observed that the band gap is likely to decrease with an increase in the $\mathrm{Fe}$ quantity. This also happens with samples of iron-doped $\mathrm{TiO}_{2}$ catalysts [30,31]. It obtained the following values for the calcination temperature at $673 \mathrm{~K}(0.5 \% \mathrm{Fe}-4.75 \mathrm{eV}$ and $1.5 \% \mathrm{Fe}-3.28 \mathrm{eV})$. It also occurred for the catalysts calcined at $873 \mathrm{~K}$. An approximate value was found for the catalyst $0.3 \%$ and $1.0 \%$ when calcined at $773 \mathrm{~K}$. It was also found that, when the calcination temperature increases, the band gap tends to increase as well. In particular, this was observed for the catalysts with a low metal nominal loading. On the other hand, Yoshimura et. al. (1996) [32] indicated band gap energies of $3.41 \mathrm{eV}$ for samples of $\mathrm{Nb}_{2} \mathrm{O}_{5}$ calcined at $773 \mathrm{~K}$, and $3.45 \mathrm{eV}$ for non-calcined samples. The values found were very similar to those presented by the other authors. The samples $1.0 \% \mathrm{Fe} / \mathrm{Nb}_{2} \mathrm{O}_{5} 913$ $\mathrm{K}$ and $0.5 \% \mathrm{Fe} / \mathrm{Nb}_{2} \mathrm{O}_{5} 873 \mathrm{~K}$ showed the highest band gap energy values of $3.94 \mathrm{eV}$, while $1.5 \%$ $\mathrm{Fe} / \mathrm{Nb}_{2} \mathrm{O}_{5} 873 \mathrm{~K}$ presented the lowest band gap energy values of $3.05 \mathrm{eV}$. This latter result $(3.05 \mathrm{eV})$ suggests that this catalyst is absorbing in regions closer to the visible region of the electromagnetic spectrum. This means that it requires less energy for electronic transactions to occur. In this context, Weibin et al. (2013) [33] reported a value of $3.70 \mathrm{eV}$, while Scheidt et al. (2014) [34] presented a band gap energy of $3.61 \mathrm{eV}$ for non-calcined $\mathrm{Nb}_{2} \mathrm{O}_{5}$ samples. Other authors such as Hamaguchi, (2011) [35], Prado et. al. (2008) [36], Liu et. al. (2011) [28] and Gallo (2016) [37] found band gap energies for $\mathrm{Nb}_{2} \mathrm{O}_{5}$ of $3.61,3.40,3.72$, and $3.60 \mathrm{eV}$, respectively.

Table 2. Result of band gaps UV-VIS.

\begin{tabular}{ccc}
\hline $\begin{array}{c}\text { Catalyst Fe/ } \mathbf{N b}_{2} \mathbf{O}_{5} \\
\mathbf{w t} \%-\mathbf{T}_{\text {Calcination }}(\mathbf{K})\end{array}$ & Band Gap (eV) & $\begin{array}{c}\text { Absorption Threshold } \\
\text { (nm) }\end{array}$ \\
\hline $0.3 \%-773$ & 3.88 & 281 \\
$0.5 \%-673$ & 3.75 & 281 \\
$0.5 \%-873$ & 3.94 & 279 \\
$1.0 \%-633$ & 3.92 & 281 \\
$1.0 \%-773$ & 3.90 & 281 \\
$1.0 \%-913$ & 3.94 & 281 \\
$1.5 \%-673$ & 3.28 & 292 \\
$1.5 \%-873$ & 3.05 & 300 \\
$1.7 \%-773$ & 3.85 & 281 \\
\hline
\end{tabular}




\subsubsection{Scanning Electron Microscopy (SEM/EDS)}

Figure 2 shows the images obtained by the scanning electron microscopy with an EDS detector (SEM/EDS), for 0.3 and $1.7 \% \mathrm{Fe} / \mathrm{Nb}_{2} \mathrm{O}_{5}$ samples calcined at $773 \mathrm{~K}$, respectively.

A
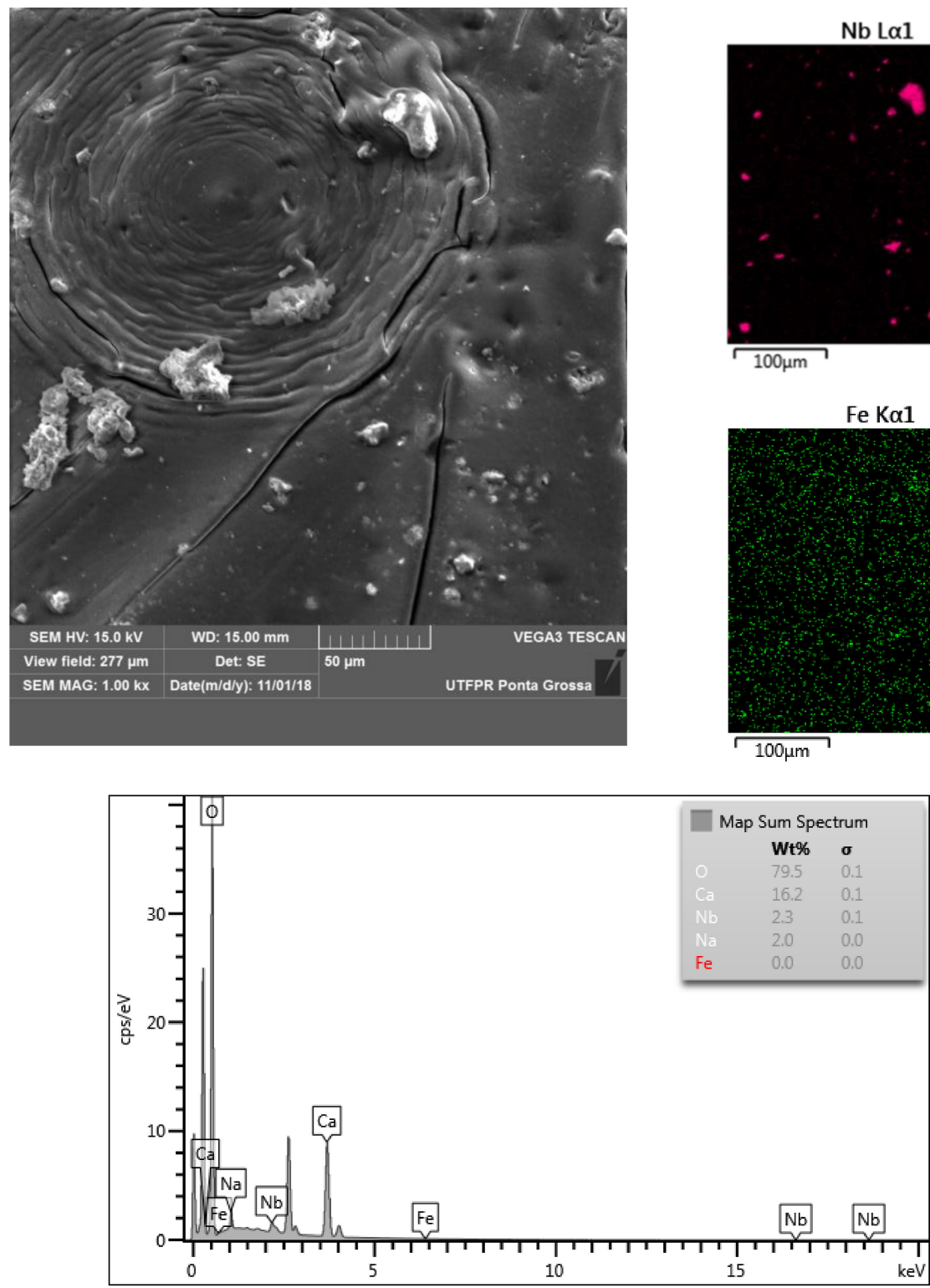

Figure 2. Cont.

Map Sum Spectrum

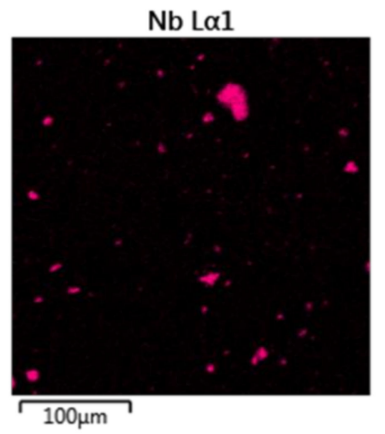

Fe Kal

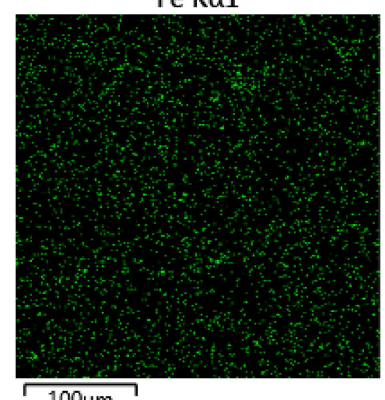

$100 \mu \mathrm{m}$ 
B


Figure 2. MEV/EDS of sample (A) $0.3 \% \mathrm{Fe} / \mathrm{Nb}_{2} \mathrm{O}_{5} 773 \mathrm{~K}$, (B) $1.5 \% \mathrm{Fe} / \mathrm{Nb}_{2} \mathrm{O}_{5}$ at $873 \mathrm{~K}$, increase $500 \times$.

Using the SEM/EDS analysis for both samples, it is possible to observe that the dispersion on the surface catalysts was homogeneous since the formation of $\mathrm{Fe} / \mathrm{Nb}_{2} \mathrm{O}_{5}$ agglomerates is distributed on the alginate sphere surface. The surface presents some rugosity, which can favor the interaction between the adsorbate and adsorbent. This benefits the catalytic activity. Similar structures on alginate spheres immobilized catalysts were reported by References $[38,39]$. Thus, it is verified that there were no major structural changes on the catalysts, and, subsequently, in the catalytic activity as well.

\subsection{Photocatalytic Reaction}

\subsubsection{Catalyst Influence}

The effect of the photocatalysis process in the TCS degradation was evaluated using $\mathrm{TiO}_{2}$ and $\mathrm{Nb}_{2} \mathrm{O}_{5}$ as catalysts (calcined at $773 \mathrm{~K}$ ). The results are shown in Figure 3. 


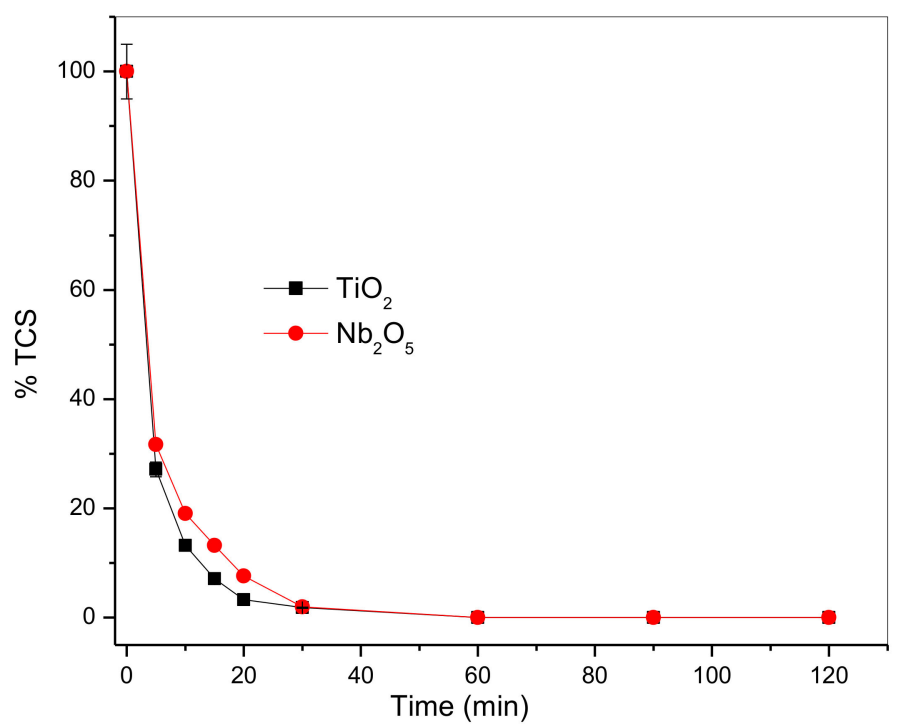

Figure 3. Influence of photo-catalysts using $\mathrm{TiO}_{2}$ and $\mathrm{Nb}_{2} \mathrm{O}_{5}$ (calcined at $773 \mathrm{~K}$ ).

The results presented in Figure 3 showed that there is no significant difference between the photo-catalysts $\mathrm{TiO}_{2}$ and $\mathrm{Nb}_{2} \mathrm{O}_{5}$ for TCS degradation. Therefore, in the next steps, the $\mathrm{Fe} / \mathrm{Nb}_{2} \mathrm{O}_{5}$ catalyst was used.

\subsection{2. $\mathrm{pH}$ Influence and Mass Catalitic}

In order to analyze the $\mathrm{pH}$ and catalyst mass influence in the TCS degradation, the conditions were verified at $\mathrm{pH} 5.5,7.0$, and 8.5 using the $1.0 \% \mathrm{Fe} / \mathrm{Nb}_{2} \mathrm{O}_{5}$ catalyst calcined at $773 \mathrm{~K}, 1 \mathrm{~g} \mathrm{~L}^{-1}$ (Figure $4 \mathrm{~A}$ ) and $0.5,1.0$, and $2.0 \mathrm{~g} \mathrm{~L}^{-1}$ catalyst (Figure $4 \mathrm{~B}$ ).

A)

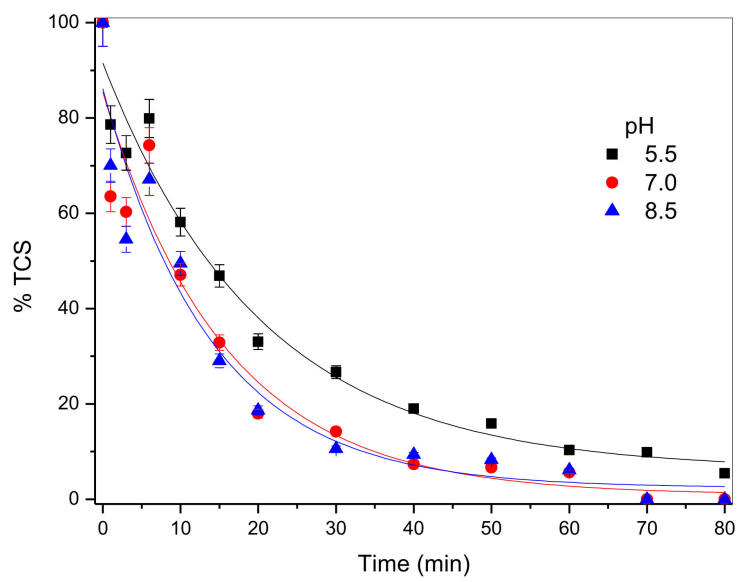

B)

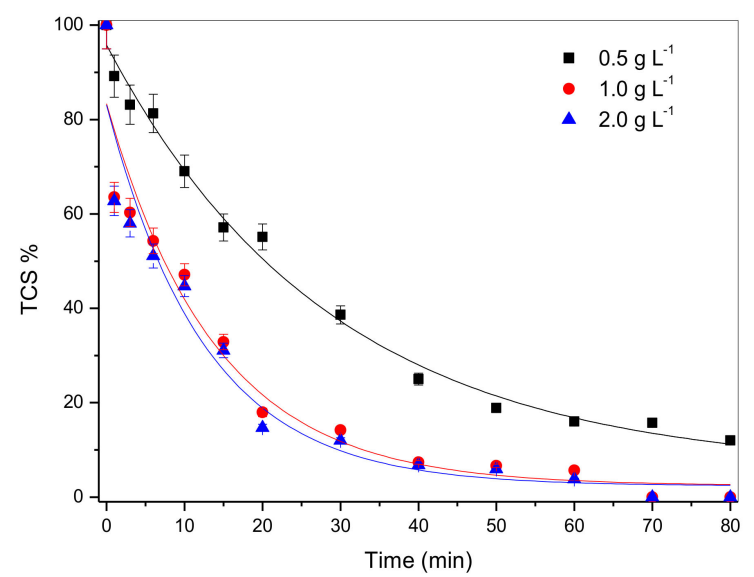

Figure 4. Influence of $(\mathbf{A}) \mathrm{pH}\left(1 \% \mathrm{Fe} / \mathrm{Nb}_{2} \mathrm{O}_{5}\right.$ calcined $\left.773 \mathrm{~K}, 1.0 \mathrm{~g} \mathrm{~L}^{-1}\right)$ and $(\mathbf{B})$ catalyst mass $(\mathrm{pH} 7.0$, $1.0 \% \mathrm{Fe} / \mathrm{Nb}_{2} \mathrm{O}_{5}$ calcined $\left.773 \mathrm{~K}\right)$.

The results indicated that, in the neutral and alkaline $\mathrm{pH}$, the TCS degradation kinetics obtained were higher than in an acidic $\mathrm{pH}$. As described in the literature, the photocatalytic efficiency of Triclosan did not change at a neutral $\mathrm{pH}$, but significantly decreased in the acidic condition by inhibiting the generation of $\mathrm{OH}$ radicals [40]. On the other hand, the degradation in $\mathrm{pH} 7.0$ and 8.5 was practically the same. A concentration of $0.5,1.0$, and $2.0 \mathrm{~g} \mathrm{~L}^{-1}$ was used to verify the catalyst mass influence. It was observed that the TCS total degradation does not occur within $80 \mathrm{~min}$ at the lowest catalyst concentration $\left(0.5 \mathrm{~g} \mathrm{~L}^{-1}\right)$. However, concentrations of 1.0 and $2.0 \mathrm{~g} \mathrm{~L}^{-1}$ showed very similar results 
(Figure 4B). Therefore, a pH 7.0 and a catalyst mass concentration of $1.0 \mathrm{~g} \mathrm{~L}^{-1}$ were maintained, in the following tests.

\subsubsection{Adsorption, Photolysis, and Photo Catalyst Tests}

The results of adsorption and photocatalytic for the TCS degradation using the $\mathrm{Fe} / \mathrm{Nb}_{2} \mathrm{O}_{5}$ immobilized catalysts are shown in Figure 5. The adsorption was performed in the first $30 \mathrm{~min}$ before the photo catalysis.

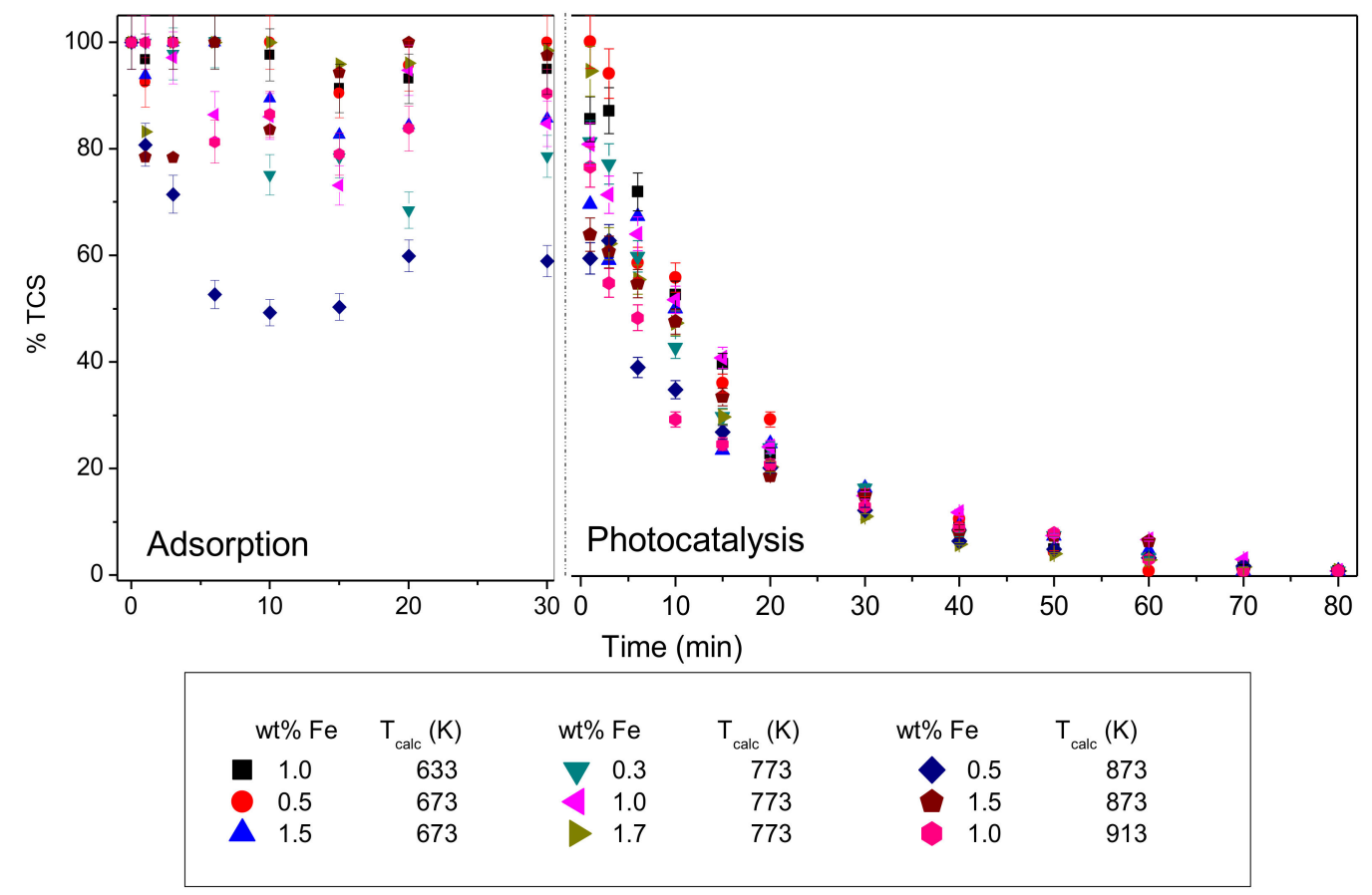

Figure 5. Adsorption and photo catalysis results $\left(\mathrm{pH}=7.0,1 \mathrm{~g} \mathrm{~L}^{-1}\right)$.

It was observed that there was an instability in the adsorption process (adsorption and desorption of TCS on catalytic surface), which indicates that only the adsorption process is not adequate for the TCS removal. In addition, it was verified that a greater adsorption does not directly imply a higher rate of degradation. For example, $0.5 \mathrm{wt} \%$ catalyst calcined at $873 \mathrm{~K}$ obtained approximately $40 \%$ adsorption. However, other catalysts saw a similar level of degradation of TCS, without the same adsorption capacity. This catalyst had a high specific surface area $\left(\sim 149 \mathrm{~m}^{2} \mathrm{~g}^{-1}\right)$. The photocatalytic degradation presented an exponential profile for all catalysts studied. The data obtained indicated that all the photo catalysts degraded the TCS after $80 \mathrm{~min}$ of the reaction.

It is also possible to verify that catalysts with higher calcination temperatures of $873 \mathrm{~K}$ and $913 \mathrm{~K}$ have a higher photocatalytic activity in the first $15 \mathrm{~min}$ of the reaction, when compared to the other catalysts used.

These values show that the photocatalytic degradation of TCS in an aqueous solution can be described by a pseudo-first order kinetic model. In addition, to compare the results obtained, the half-life $\left(t_{1 / 2}\right)$ was evaluated, which indicates the approximate time required for the contaminant concentration to be halved.

Its half-life was calculated according to Equation (1), where $k$ is the constant reaction rate. The results are shown in Table 3.

$$
t_{\left(\frac{1}{2}\right)}=-\frac{\ln \left(\frac{1}{2}\right)}{k}
$$


Table 3. Half-life $t_{1 / 2}$, first-order reaction rate constant results.

\begin{tabular}{cccc}
\hline wt $\%-\mathbf{T}_{\text {calcination }}(\mathbf{K})$ & $\mathbf{k}\left(\mathbf{m i n}^{-\mathbf{1}}\right)$ & $\mathbf{t}_{\mathbf{1 / 2}}(\mathbf{m i n})$ & $\mathbf{R}^{\mathbf{2}}$ \\
\hline $0.3 \%-773$ & 0.0570 & 12.16048 & 0.97926 \\
$0.5 \%-673$ & 0.0666 & 10.40605 & 0.98392 \\
$0.5 \%-873$ & 0.0595 & 11.64953 & 0.98398 \\
$1.0 \%-633$ & 0.0623 & 11.12596 & 0.99583 \\
$1.0 \%-773$ & 0.0500 & 13.86294 & 0.97886 \\
$1.0 \%-913$ & 0.0538 & 12.89336 & 0.93194 \\
$1.5 \%-673$ & 0.0514 & 13.48535 & 0.96524 \\
$1.5 \%-873$ & 0.0690 & 10.04561 & 0.93221 \\
$1.7 \%-773$ & 0.0670 & 10.34548 & 0.99106 \\
\hline
\end{tabular}

Among all the catalysts, the $1.5 \% \mathrm{Fe} / \mathrm{Nb}_{2} \mathrm{O}_{5}$ calcined at $873 \mathrm{~K}$ was the one with the highest constant reaction rate and the lowest half-life of $0.069 \mathrm{~min}^{-1}$ and $10.04 \mathrm{~min}$. Another relevant characteristic is that it has the smallest band gap $(3.05 \mathrm{eV})$. Figure 5 shows a comparison degradation kinetics of TCS between photo catalysis $\left(1.5 \% \mathrm{Fe} / \mathrm{Nb}_{2} \mathrm{O}_{5}\right.$ calcined at $\left.873 \mathrm{~K}\right)$ and photolysis. The experiments were performed in different matrices, ultrapure water, and water containing $\mathrm{Cl}^{-}$. The reaction orders, rate constant, and $t_{1 / 2}$ are shown in the subtitle of Figure 6.

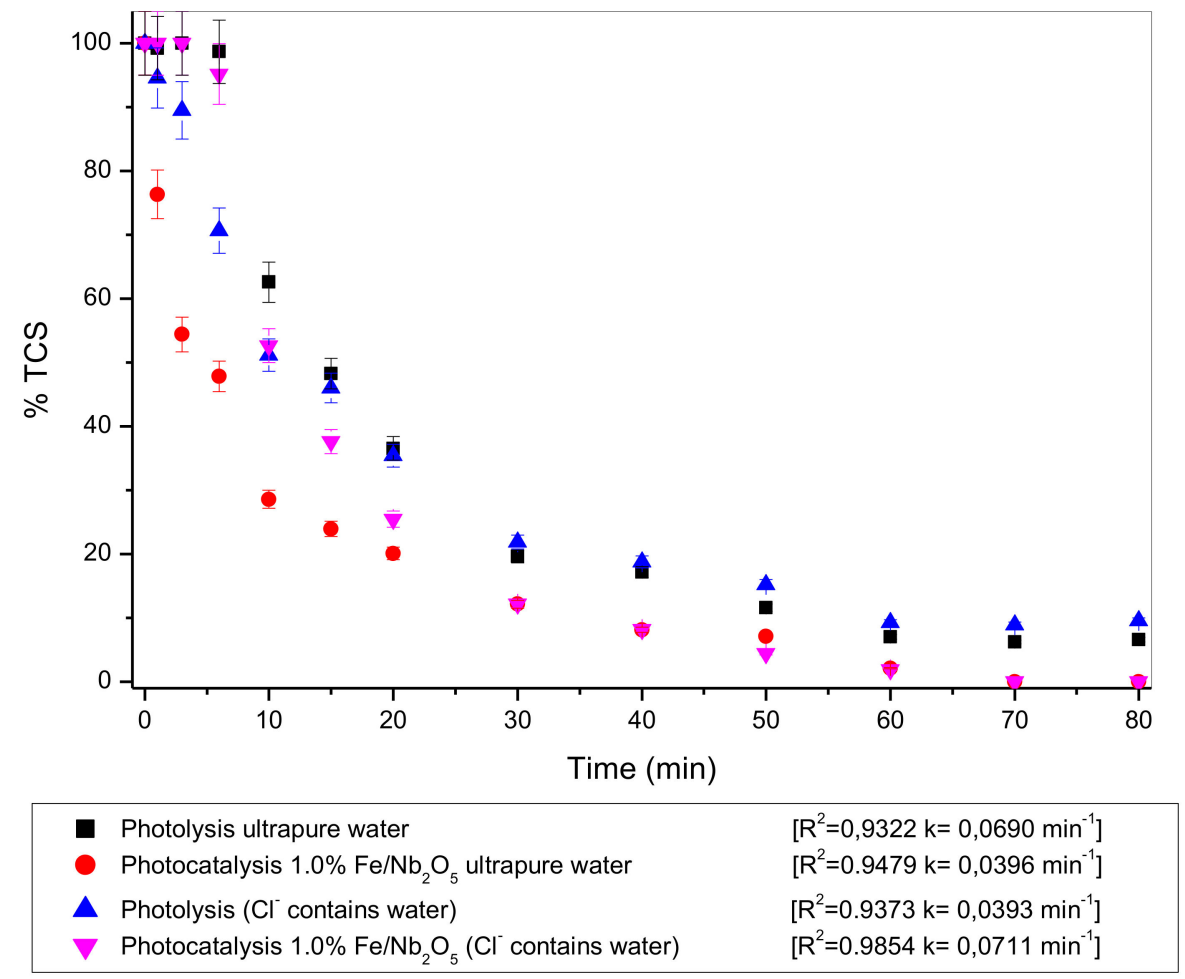

Figure 6. Photo catalysis and photolysis in different matrices.

In Figure 7 , it can be verified that the photo catalysis is more efficient in the $100 \%$ degradation of TCS, which does not occur for photolysis. In both matrices used, the photo catalysis was efficient. 


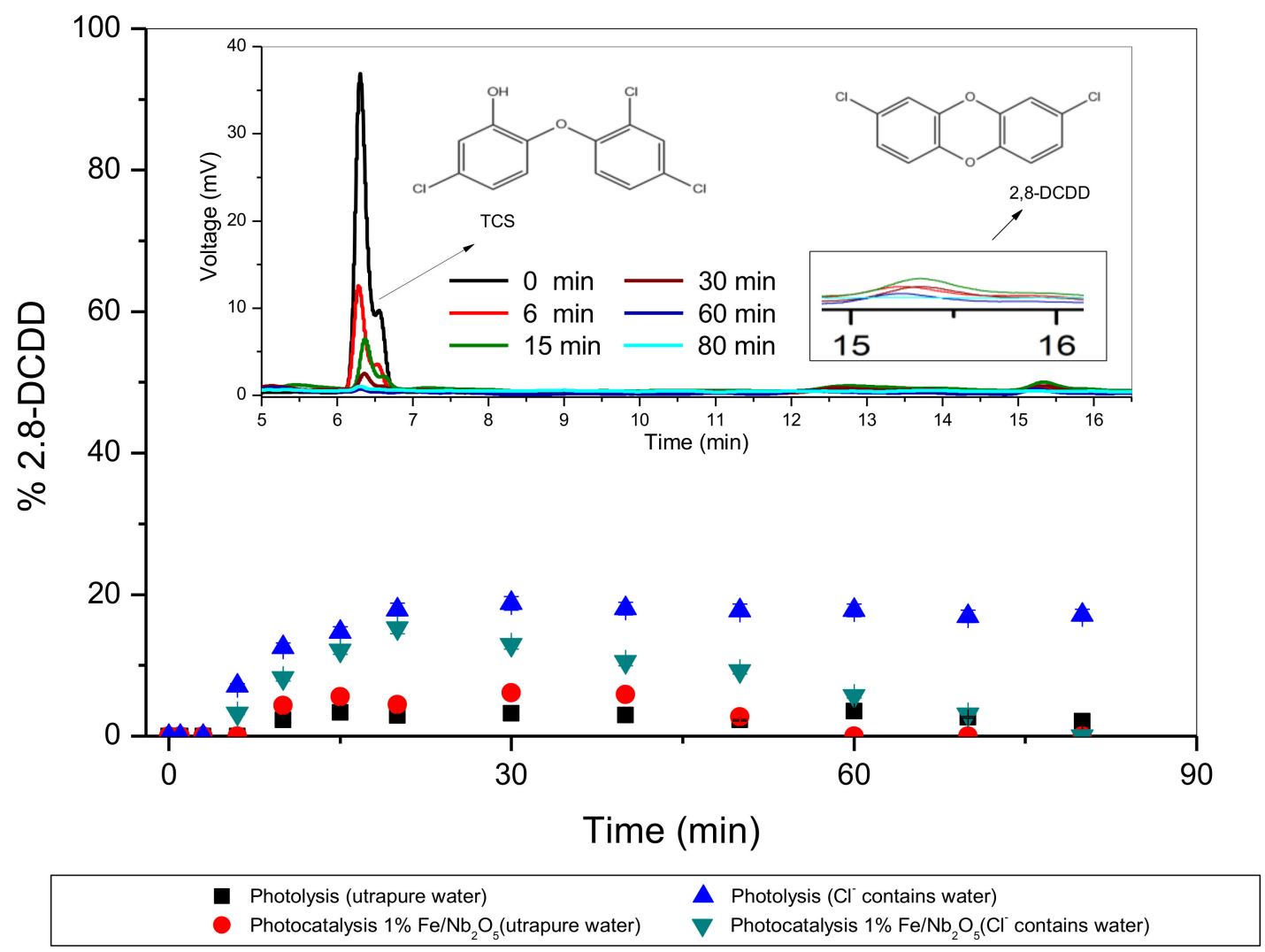

Figure 7. Generation of 2.8-DCDD from photocatalytic and photolytic processes in different matrices.

At the same time, an analysis on the generation/degradation of 2.8-DCDD was performed, where the TCS in the presence of $\mathrm{Cl}^{-}$and radiation, is transformed into this compound.

Figure 7 shows that 2.8-DCDD has a kinetics of higher formation in matrices containing $\mathrm{Cl}^{-}$, which was previously described by Reference [6]. It is also noted that, in these environments, the transformation of TCS into 2,8-DCDD occurs extremely fast in approximately $20 \mathrm{~min}$. It is observed that the photolysis is not efficient in the 2.8-DCDD degradation. However, the photocatalysis is able to degrade it completely after 80 min of reaction.

Then the formation of hydroxyl radicals $(\cdot \mathrm{OH})$ occur. According to Reference [5], two conditions need to be satisfied for the formation of DCDDs and DCHDFs (dichlorohydroxydibenzofurans). First, . $\mathrm{OH}$ radicals are present for the cleavage and oxidation. Second, the chlorinated phenoxyphenols are not to be de-chlorinated into phenoxyphenols before they react with $\cdot \mathrm{OH}$.

Iron leaching tests were performed in triplicate. The concentrations of iron were determined by Flame atomic absorption spectrometry (F AAS) using a spectrometer (Perkin Elmer AAnalyst 700, Lübeck, Germany). The results indicated that leaching of Fe does not occur.

\subsubsection{Photo Stability}

To evaluate photo stability, tests in successive cycles ( $80 \mathrm{~min}$ each) were performed (Figure 8) and $1.5 \% \mathrm{Fe} / \mathrm{Nb}_{2} \mathrm{O}_{5}$ calcined at $873 \mathrm{~K}$ were used. In the first cycle, a TCS degradation of about $91 \%$ occurs, decreasing to $89 \%$ in the first reuse cycle, $68 \%$ in the second reuse, and reaching only $50 \%$ in the third reuse cycle. This time is sufficient to TCS and 2.8-DCDD degradation. However, the catalytic deactivation may be related with surface adsorbed compounds and by-products formed in the reaction. 


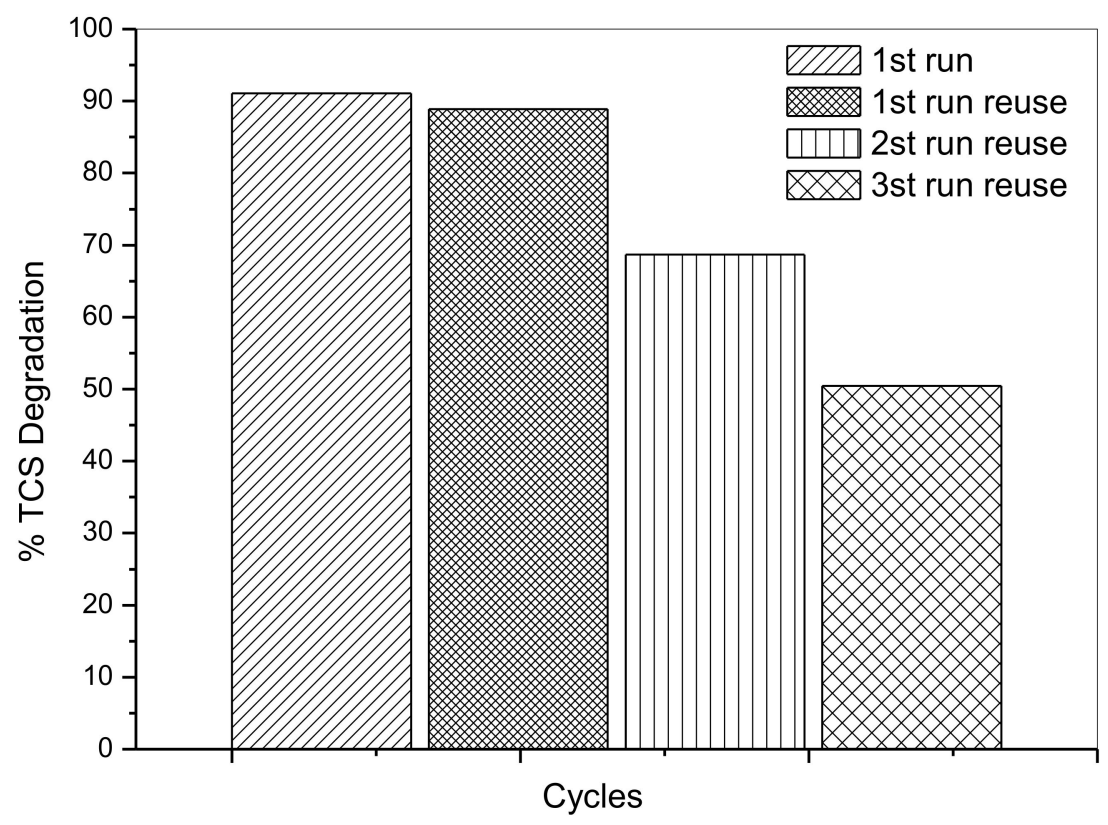

Figure 8. Photocatalytic reuse cycle $\left(1.5 \% \mathrm{Fe} / \mathrm{Nb}_{2} \mathrm{O}_{5}\right.$ calcined at $\left.873 \mathrm{~K}\right)$.

\subsection{Experimental Design and Optimization}

The effects on the parameters of the nominal load of metal $(\% \mathrm{Fe})$ and calcination temperature on the TCS degradation were investigated.

According to the results obtained in the Response surface and Surface Contour (Figure 9A,B) and the e Pareto chart (Figure 10), all variables studied were significant for the process.

It was mainly observed that the effects are more accentuated at higher calcination temperatures and higher iron percentages. These are two conditions that significantly affect the photocatalytic process.

From the data obtained, it was possible to table a new construct with $R^{2}=0.98204$ presented in Table 4 .

Table 4. Analysis of variance.

\begin{tabular}{cccccc}
\hline $\begin{array}{c}\text { Source of } \\
\text { Variation }\end{array}$ & $\begin{array}{c}\text { Sum of } \\
\text { Squares (SS) }\end{array}$ & $\begin{array}{c}\text { Degrees of } \\
\text { Freedom (df) }\end{array}$ & $\begin{array}{c}\text { Mean Square } \\
\text { (MS) }\end{array}$ & F & Prob $>$ F \\
\hline Regression & 115.4253 & 5 & 23.08506 & 54.66544 & 5.05 \\
Resisual & 2.1115 & 5 & 0.422297 & & 19.16 \\
Lack of Fit & 2.0356 & 3 & 0.678545 & 17.891521 & - \\
Pure erro & 0.0759 & 2 & 0.037925 & - & - \\
Total & 117.5368 & 10 & - & & - \\
\hline
\end{tabular}

In order to verify if the generated model was significant, the statistical test $\mathrm{F}$ was used as a basis. For $\alpha=0.05$, we have F (Reg, Res) $5.5>$ F (Tab) 5.5 and F (Err) 3.2 < F (Tab) 3.2. Subsequently, it can confidently be concluded to a percentage of $95 \%$ that the generated model is significant and there is no evidence of significant differences between treatments. 
A)

Fitted Surface; Variable: DV_ 1

2 factors, 1 Blocks, 11 Runs; MS Pure Error=0.0379255

DV: DV_ 1

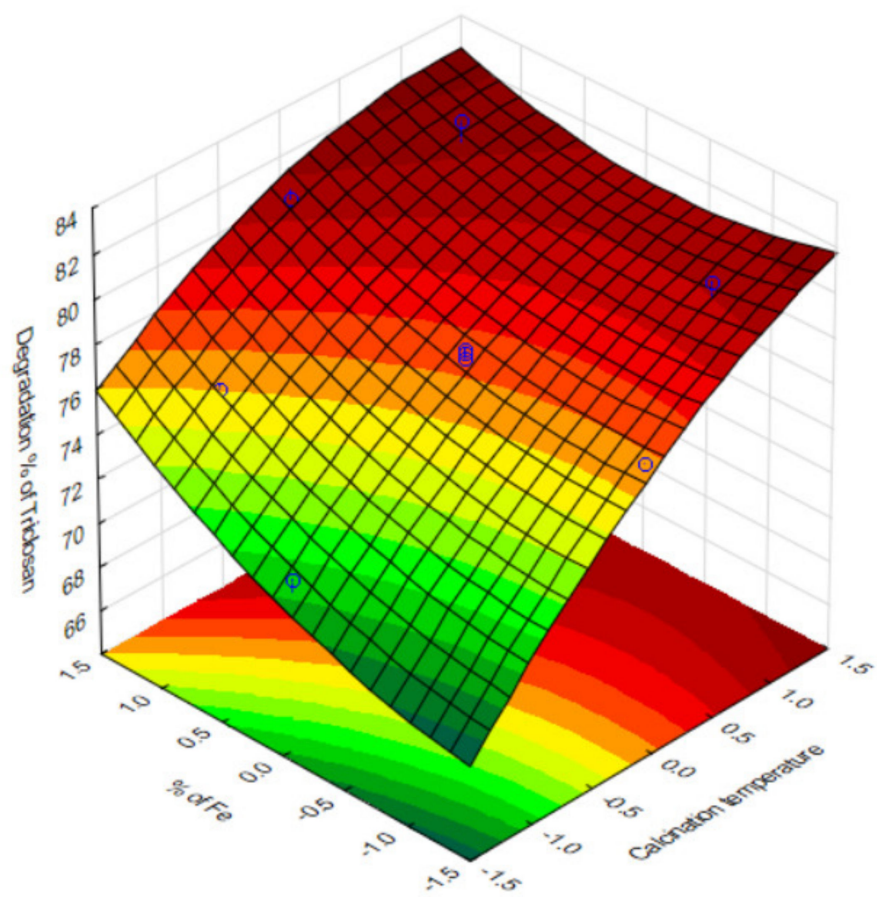

B)

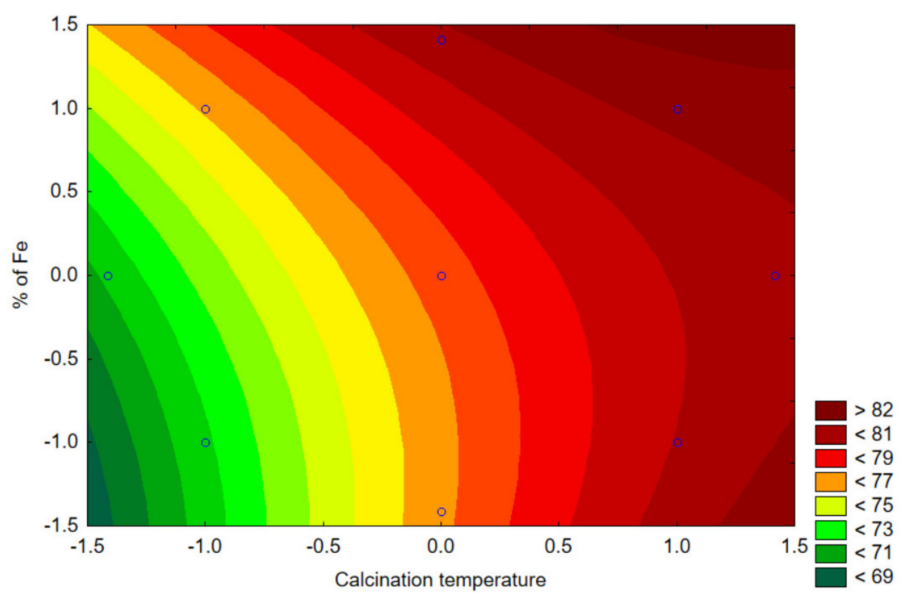

Figure 9. (A) Response surface plot for degradation TCS by $\mathrm{Nb}_{2} \mathrm{O}_{5}$ versus wt $\% \mathrm{Fe}$ and Temperature Calcination. (B) Surface contour obtained in the experimental design. (Coded variable Table 5). 


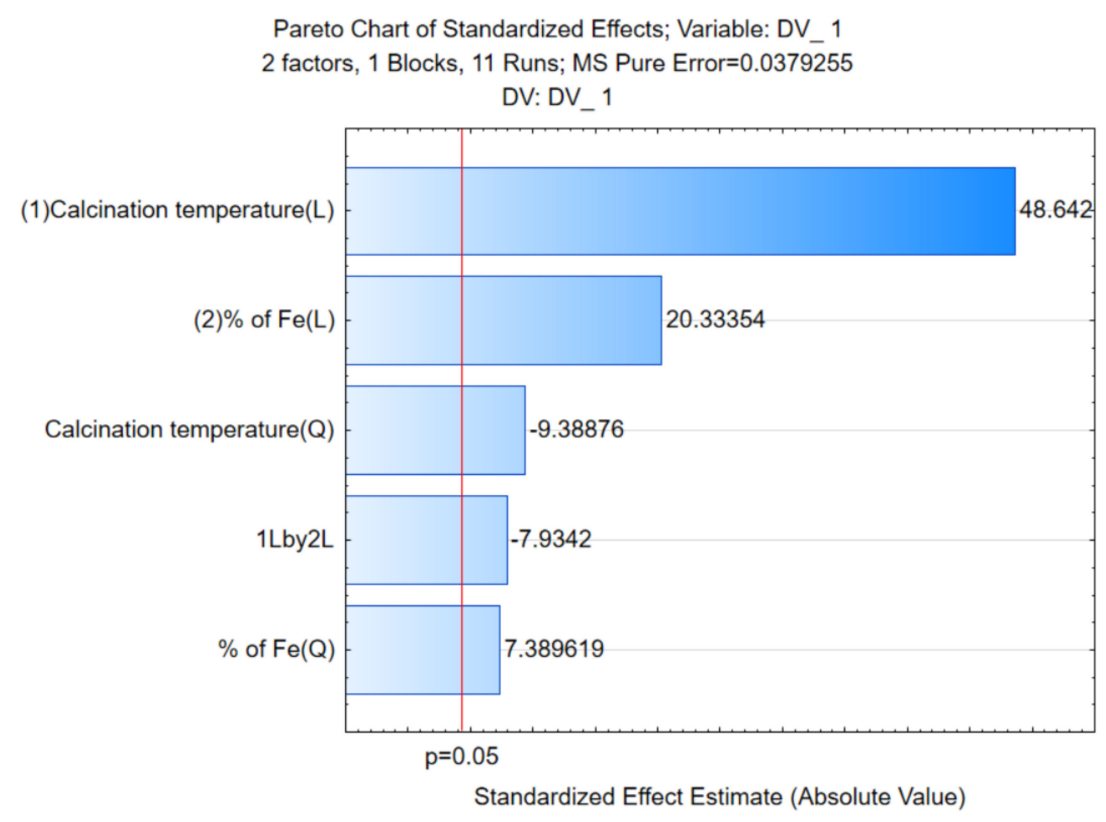

Figure 10. Pareto chart $\left(\mathrm{pH}=7.0,1 \mathrm{~g} \mathrm{~L}^{-1}\right.$, and $20 \mathrm{~min}$ of reaction).

\section{Materials and Methods}

Chemicals: Acetonitrile (HPLC-supplied by J.T.Barker, Ciudad de México, México) PA-ACS-CH3CN. Panreac-AppliChem., Triclosan-(supplied by Merck, Darmstadt, Germany); Niobium pentoxide hydrated (Nb2O5) (supplied by CBMM-Companhia Brasileira de Matalurgia e Mineração, Araxá, Minas Gerais, Brasil), Iron Nitrate III (ICO) nonohydrate P.A. ACS $\left(\mathrm{Fe}\left(\mathrm{NO}_{3}\right) \cdot 3 \cdot 9 \cdot \mathrm{H}_{2} \mathrm{O}\right)$ (supplied by SYNTH, São Paulo, Brasil), Sodium Alginate (P.A) (supplied by Sigma Aldrich, St Louis, MO, USA), and Calcium Chloride-(P.A.) (supplied by Nuclear, São Paulo, Brasil).

\section{1. $\mathrm{Fe} / \mathrm{Nb}_{2} \mathrm{O}_{5}$ Immobilized Synthesis}

The catalyst synthesis was performed in two stages: (i) Impregnation method-used for supported iron on niobium, with solvent in excess, with different nominal metal loads $(0.3 \%, 0.5 \%, 1.0 \%, 1.5 \%$ and $1.7 \%)$, as described by Reference [33,41]. It was then dried in a rotary evaporator and stove to remove the solvent in excess. Afterward, it was then calcined at different temperatures $(633,673,773,873$, and $913 \mathrm{~K}$ ) with heating ramps. (ii) Catalytic immobilization—for the catalyst immobilization, it used a methodology adapted from Reference [31], which incorporated sodium alginate as the polymer matrix. The concentrations used were: sodium alginate $2 \%(w / v)$ and photocatalyst $1 \mathrm{~g} \mathrm{~L}^{-1}$. The catalyst was agitated with sodium alginate in a solution and then dripped in a $2 \%(w / v)$ calcium chloride solution $\left(\mathrm{CaCl}_{2}\right)$ in a $288 \mathrm{~K}$ ultra-thermostatic bath to form the sodium alginate beads. After 24 hours, the beads were washed with ultrapure water and oven dried at $333 \mathrm{~K}$ for 8 hours.

\subsection{Characterization}

Textural Properties: Porous properties such as specific surface area, mean pore diameter, and pore volume were established using a QUANTACHROME Analyzer-Model Novatouch 2 LX with N ${ }^{2}$ adsorption at $77 \mathrm{~K}$. The samples were previously submitted to a thermal treatment at $333 \mathrm{~K}$ for 12 hours, which puts them under vacuum to eliminate any existing water within the pores of the solids. Photoacoustic spectroscopy (PAS): The photoacoustic spectroscopy measurements in the UV-VIS spectral regions were performed using a lab-made experimental setup.

It obtained a monochromatic light through a 1000-Watt xenon arc lamp (66926, Newport Corporation/Oriel) and a monochromator (74100, Newport Corporation by Oriel Instruments, São Paulo, São Paulo, Brasil. The light beam was modulated using a mechanical chopper 
(SR540-Stanford Research Systems). A lab-made photoacoustic cell was designed to have a very low volume and was made of aluminum block. It was machined to hold samples with dimensions of up to $10 \mathrm{~mm}$ in diameter and $1.5 \mathrm{~mm}$ in thickness. This allowed light to enter through a high transparent quartz window of a 6-mm diameter and 2-mm thickness. The distance of the microphone chamber was $15 \mathrm{~mm}$. It was connected to the sample holder room through a 1-mm diameter duct. The capacitive microphone (4953, Brüel\&Kjaer) used was a $12-\mathrm{mm}$ diameter. It was very sensitive and presented a gain of $50 \mathrm{mV} / \mathrm{Pa}$, and a flat frequency response between 3 to $10 \mathrm{kHz}$. It also used a lock-in amplifier (SR830, Stanford Research System). All the photoacoustic spectra were obtained at a $23 \mathrm{~Hz}$ modulation frequency and recorded between 225 to $700 \mathrm{~nm}$. Data was acquired using a personal computer, and the PAS spectra were normalized regarding the carbon black signal. The band gap energies were established through Equation (2):

$$
\lambda=\frac{h c}{E_{g a p}}=\frac{1240}{E_{g a p}}
$$

where $E_{g a p}$ is the band gap energy in $\mathrm{eV}$ units. The direct method was applied to obtain the values, i.e., $\mathrm{m}=2$.

X-ray diffraction: The samples were measured through a Rigaku-Denki Diffractometer with $\mathrm{Cu}-\mathrm{K} \alpha$ radiation $(\lambda=1.5406 \AA)$ at $40 \mathrm{kV}$ voltage and $40 \mathrm{~mA}$ current. Subsequently, the obtained patterns were compared with the diffraction dataset cards from the ICDD.

Scanning electron microscopy (SEM/EDS): For the analysis, a scanning electron microscope (model VEGA 3 LMU, brand TESCAN) was used, complete with $\mathrm{W} 30 \mathrm{kV}$ filament, $3.0 \mathrm{~nm}$ resolution, SE detectors, and retractable BSE. It also featured a low vacuum mode (500 Pa), chamber with internal diameter of $230 \mathrm{~mm}$, and a door width of $148 \mathrm{~mm}$. The microscope also included compucentric rotation, 5-axis fully motorized, with X movement: $80 \mathrm{~mm}, \mathrm{Y}: 60 \mathrm{~mm}$ and Z: $47 \mathrm{~mm}, \mathrm{CCD}$ camera for viewing samples, and "chamberview" software, VegaTC operational software, data processing system, and track-ball. The Microscope is also equipped with the EDS detector, dry, model AZTec Energy X-Act, resolution $130 \mathrm{eV}$, brand Oxford.

\subsection{Photocatalytic Tests}

The reaction mixture was transferred to a reactor consisting of a cylindrical Pyrex cell $\left(5.0 \times 10^{-4} \mathrm{~m}^{3}\right)$ surrounded by a water jacket and a magnetic stirrer. This was used to ensure a constant temperature $(298 \mathrm{~K})$ with ultra-thermostatic bath and solution homogeneity throughout the experiment. The tests were performed for $80 \mathrm{~min}$ and opened to the air. Oxygen was pumped at $8.3 \times 10^{-9} \mathrm{~m}^{3} \mathrm{~s}^{-1}$ into the solution containing $10 \mathrm{ppm}$ of TCS and a photo catalyst. The TCS $10 \mathrm{mg} \mathrm{L}^{-1}$ solution was prepared with $70 \%$ of acetonitrile and $30 \%$ of ultrapure water. A total of $500 \mathrm{~mL}$ was inserted into the reactor, along with the catalyst mass. UV light was irradiated by using a 125-W medium pressure mercury lamp, the radiation incidence was measured $\left(2.48 \mathrm{~mW} / \mathrm{cm}^{2}\right)$. Aliquots were collected at regular intervals of time. Chromatographic analysis of Triclosan was performed with a high performance liquid chromatograph YL Clarity model 9100 equipped with a pre-column, reverse phase C-18 column, and visible ultraviolet detector (UV-VIS). It used the standard acetonitrile HPLC for chemical analysis and the $\mathrm{pH}$ control of sodium hydroxide and nitric acid.

Different conditions were studied: $\mathrm{pH} 5.5,7.0$, and 8.5, catalyst mass $0.5,1.0$, and $2.0 \mathrm{~g} \mathrm{~L}^{-1}$ and calcination temperature of the catalyst between 633 and $913 \mathrm{~K}$. The adsorption tests were performed by applying the same procedures of the previous photocatalytic test, but without the presence of light. The photolysis experiments were conducted using no catalysts and followed the same procedures of the photocatalytic tests. The tests were completed twice.

Tests about photo stability were performed in four successive cycles. Between the cycles, the catalyst was filtered, washed (ultrapure water), and dried. 


\subsection{Optimization of Experimental Parameters}

The effects of operating parameters of TCS degradation using the $\mathrm{Fe} / \mathrm{Nb}_{2} \mathrm{O}_{5}$ catalyst were analyzed by using a central composite factorial. The general form of this factorial design is $2 \mathrm{n}$ plus a star configuration $\left( \pm \alpha=2^{n^{(1 / 4)}}\right)$, with a central point, where $\mathrm{n}$ and 2 represent the number of factors and the two levels of work [33], respectively. The levels are defined as low level (-1), high level (+1), central point (0), and two outer points. The independent variables were the Calcination Temperature of catalysts and nominal metal load (\%Fe), while the dependent variable Y (variable response) was the TCS removal percentage. The settings for the independent variables were as follows (low/high value): calcination Temperature: 633 to $913 \mathrm{~K}$, and nominal metal load: 0.3 to $1.7 \%$ Fe. Table 5 shows experimental results of the independent variables. The values for coded and decoded variables are also shown.

Table 5. Design matrix and experimental results for the central composite factorial design.

\begin{tabular}{ccc}
\hline Run & Calcination Temperature (K) & \%Fe and (Coded Variable) \\
\hline 1 & $873(+1)$ & $1.5(+1)$ \\
2 & $873(+1)$ & $0.5(-1)$ \\
3 & $673(-1)$ & $1.5(+1)$ \\
4 & $673(-1)$ & $0.5(-1)$ \\
5 & $913(+\alpha)$ & $1.0(0)$ \\
6 & $633(-\alpha)$ & $1.0(0)$ \\
7 & $773(0)$ & $0.3(-\alpha)$ \\
8 & $773(0)$ & $1.7(+\alpha)$ \\
9 & $773(0)$ & $1.0(0)$ \\
10 & $773(0)$ & $1.0(0)$ \\
11 & $773(0)$ & $1.0(0)$ \\
\hline
\end{tabular}

\section{Conclusions}

The $\mathrm{Fe} / \mathrm{Nb}_{2} \mathrm{O}_{5}$ immobilized catalysts were efficient in the Triclosan and 2,8-dichlorodibenzenep-dioxin degradation. The characterization indicated that a variation in the specific surface area occurs for the catalysts studied. This is influenced by the calcination temperature and nominal metal loading.

In the XRD analysis, catalysts calcined at $673 \mathrm{~K}$ or at lower temperatures have a non-crystalline structure. Above this calcination temperature, structures in the form $T$ and TT were found. The band gap results, in general, see a decrease of the band gap in accordance with an increase in the nominal metallic charge of Fe. On the other hand, when the calcination temperature increases, the band gap also tends to increase. The SEM/EDS analysis showed the formation of agglomerates throughout the sphere surface and rugosity. The photocatalytic tests indicated that the operating optimum conditions were $\mathrm{pH} 7.0$ and catalyst mass of $1.0 \mathrm{~g} \mathrm{~L}^{-1}$. The adsorption process is not efficient for the TCS removal and a higher adsorption on the catalytic surface does not imply a faster photocatalytic process. All catalysts were efficient in the TCS degradation after $80 \mathrm{~min}$ of reaction. The catalysts $1.5 \% \mathrm{Fe} / \mathrm{Nb}_{2} \mathrm{O}_{5}$ calcined at $873 \mathrm{~K}$ showed the highest constant reaction rate and the lowest half-life $-0.069 \mathrm{~min}^{-1}$ and $10.04 \mathrm{~min}$. This was, consequently, the best catalyst studied.

Photo catalysis was efficient (100\% degradation) in both matrices studied (ultrapure and water containing $\mathrm{Cl}^{-}$). On the other hand, this did not occur with photolysis. In the process, the generation and subsequent degradation of 2.8-DCDD occurred. This degradation was larger in matrices containing $\mathrm{Cl}^{-}$, since it was totally degraded after $80 \mathrm{~min}$ of reaction. The parameters studied (nominal metal load $(\% \mathrm{Fe})$ and calcination temperature) in the experimental design and optimization were significant for the process. From the results obtained, it was concluded that the greater the amount of Fe percentage and calcination temperature, the better the result.

Author Contributions: M.Z.F, E.A., and E.S.C. carried out the experiment, conceived, and planned the experiments. R.B. and D.T.D. Characterization Analysis. G.G.L. and O.A.A.D.S. original draft preparation. All authors discussed the results and contributed to the final manuscript. 
Acknowledgments: The authors thank the CBMM-CompanhiaBrasileira de Matalurgia e Mineração by the Niobium, and $\mathrm{CNPq}$ agency.

Conflicts of Interest: The authors declare no conflict of interest.

\section{References}

1. Bedoux, G.; Roig, B.; Thomas, O.; Dupont, V.; Le Bot, B. Occurrence and toxicity of antimicrobial triclosan and by-products in the environment. Environ. Sci. Pollut. Res. 2012, 19, 1044-1065. [CrossRef]

2. Reiss, R.; Mackay, N.; Habig, C.; Griffin, J. An ecological risk assessment for triclosan in lotic systems following discharge from wastewater treatment plants in the United States. Environ. Toxicol. Chem. 2002, 21, 2483-2492. [CrossRef]

3. Singer, H.; Müller, S.; Tixier, C.; Pillonel, L. Triclosan: Occurrence and Fate of a Widely Used Biocide in the Aquatic Environment: Field Measurements in Wastewater Treatment Plants, Surface Waters, and Lake Sediments. Environ. Sci. Technol. 2002, 36, 4998-5004. [CrossRef] [PubMed]

4. Wang, J.L.; XU, L.J. Advanced oxidation processes for wastewater treatment: formation of hydroxyl radical and application. Crit. Rev. Environ. Sci. Technol. 2012, 42, 251-325. [CrossRef]

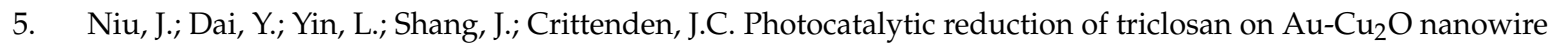
arrays as plasmonic photoatalysts under visible light irradiation. Phys. Chem. Chem. Phys. 2015, 17, 17421-17428. [CrossRef] [PubMed]

6. Buth, J.M.; Steen, P.O.; Sueper, C.; Blumentritt, D.; Vikesland, P.J.; Arnold, W.A.; McNeill, K. Dioxin Photoproducts of Triclosan and Its Chlorinated Derivatives in Sediment Cores. Environ. Sci. Technol. 2010, 44, 4545-4551. [CrossRef]

7. UNEP-United Nations Environment Programme. Persistent Organic Pollutants. 2013. Available online: http:/ / www.chem.unep.ch/pops / (accessed on 22 January 2018).

8. Chen, J.; Huang, Y.; Li, G.; An, T.; Hu, Y.; Li, Y. VOCs elimination and health risk reduction in e-waste dismantling workshop using integrated techniques of electrostatic precipitation with advanced oxidation technologies. J. Hazard. Mater. 2016, 302, 395-403. [CrossRef] [PubMed]

9. Zeng, Z.-Q.; Wang, J.-F.; Li, Z.-H.; Sun, B.-C.; Shao, L.; Li, W.-J.; Zou, H.-K. The Advanced Oxidation Process of Phenol Solution by O3/H2O2in a Rotating Packed Bed. Ozone Sci. Eng. 2013, 35, 101-108. [CrossRef]

10. Abdullah, A.M.; Al-Thani, N.J.; Tawbi, K.; Al-Kandari, H. Carbon/nitrogen-doped $\mathrm{TiO}_{2}$ : New synthesis route, characterization and application for phenol degradation. Arab. J. Chem. 2016, 9, 229-237. [CrossRef]

11. Pelaez, M.; Nolan, N.T.; Pillai, S.C.; Seery, M.K.; Falaras, P.; Kontos, A.G. A review on the visible light active titanium dioxide photocatalysts for environmental applications. Appl. Catal. B Environ. 2012, 125, 331-349. [CrossRef]

12. Espino-Estévez, M.R.; Fernández-Rodríguez, C.; González-Díaz, O.M. Effect of $\mathrm{TiO}_{2}-\mathrm{Pd}$ and $\mathrm{TiO}_{2}-\mathrm{Ag}$ on the photocatalytic oxidation of diclofenac, isoproturon and phenol. Chem. Eng. J. 2016, 298, 82-95. [CrossRef]

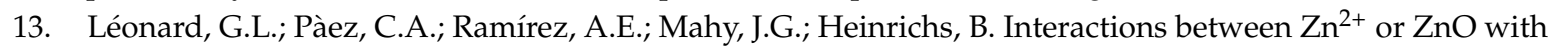
$\mathrm{TiO}_{2}$ to produce an efficient photocatalytic, superhydrophilic and aesthetic glass. J. Photochem. Photobiol. A Chem. 2018, 350, 32-43. [CrossRef]

14. Yan, J.; $\mathrm{Wu}, \mathrm{G} . ; \mathrm{Guan}, \mathrm{N} . ; \mathrm{Li}, \mathrm{L} . \mathrm{Nb}_{2} \mathrm{O}_{5} / \mathrm{TiO}_{2}$ heterojunctions: Synthesis strategy and photocatalytic activity. Appl. Catal. B 2014, 152-153, 280-288. [CrossRef]

15. Kalan, R.E.; Yaparatne, S.; Amirbahman, A.; Tripp, C.P. P25 titanium dioxide coated magnetic particles: Preparation, characterization and photocatalytic activity. Appl. Catal. B 2016, 187, 249-258. [CrossRef]

16. Castro, D.C. Síntese de $\mathrm{Nb}_{2} \mathrm{O}_{5}$ mesoporo para aplicação em fotocatálise heterogênea. Master's Degree, Universidade Federal de Mato Grosso do Sul, Campo Grande, MS, Brazil, 2014.

17. Zhao, Y.; Zhou, X.; Ye, L.; Chi Edman Tsang, S. Nanostructured $\mathrm{Nb}_{2} \mathrm{O}_{5}$ catalysts. Nano Rev. 2012, $3,17631$. [CrossRef]

18. Dong, Y.; Tang, D.; Li, C. Photocatalytic oxidation of methyl orange in water phase by immobilized $\mathrm{TiO}_{2}$-carbon nanotube nanocomposite photocatalyst. Appl. Surf. Sci. 2014, 296, 1-7. [CrossRef]

19. Katsaros, G.; Stergiopoulos, T.; Arabatzis, I.; Papadokostaki, K.; Falaras, P. A solvent-free composite polymer/inorganic oxide electrolyte for high efficiency solid-state dye-sensitized solar cells. J. Photochem. Photobiol. 2002, 149, 191-198. [CrossRef] 
20. Sakkas, V.; Arabatzis, I.; Konstantinou, I.; Dimou, A.; Albanis, T.; Falaras, P. Metolachlor photocatalytic degradation using $\mathrm{TiO}_{2}$ photocatalysts. Appl. Catal. B Envioron. 2004, 49, 195-205. [CrossRef]

21. Santos, L.M.; Machado, W.A.; França, M.D.; Borges, K.A.; Paniago, R.M.; Patrocinio, A.O.T.; Machado, A.E.H. Structural characterization of Ag-doped TiO2 with enhanced photocatalytic activity. RSC Adv. 2015, 5, 103752-103759. [CrossRef]

22. Arcanjo, G.S.; Mounteer, A.H.; Bellato, C.R.; da Silva, L.M.M.; Brant Dias, S.H.; da Silva, P.R. Heterogeneous photocatalysis using $\mathrm{TiO}_{2}$ modified with hydrotalcite and iron oxide under UV-visible irradiation for color and toxicity reduction in secondary textile mill effluent. J. Environ. Manage. 2018, 211, 154-163. [CrossRef]

23. Yadav, H.M.; Otari, S.V.; Koli, V.B.; Mali, S.S.; Hong, C.K.; Pawar, S.H.; Delekar, S.D. Preparation and characterization of copper-doped anatase $\mathrm{TiO}_{2}$ nanoparticles with visible light photocatalytic antibacterial activity. J. Photochem. Photobiol. 2014, 280, 32-38. [CrossRef]

24. Fontana, K.B.; Chaves, E.S.; Kosera, V.S.; Lenzi, G.G. Barium removal by photocatalytic process: An alternative for water treatment. J. Water Process Eng. 2018, 22, 163-171. [CrossRef]

25. Nakajima, K.; Baba, Y.; Noma, R.; Kitano, M.N.; Kondo, J.; Hayashi, S.; Hara, M. $\mathrm{Nb}_{2} \mathrm{O}_{5} \cdot \mathrm{nH}_{2} \mathrm{O}$ as a Heterogeneous Catalyst with Water-Tolerant Lewis Acid Sites. J. Am. Chem. Soc. 2011, 133, 4224-4227. [CrossRef]

26. Morais, L.A.; Adán, C.; Araujo, A.S.; Guedes, A.P.M.A.; Marugán, J. Synthesis, Characterization, and Photonic Efficiency of Novel Photocatalytic Niobium Oxide Materials. Glob. Chall. 2017, 1, 1700066. [CrossRef]

27. Sreethawong, T.; Ngamsinlapasathian, S.; Yoshikawa, S. Crystalline mesoporous $\mathrm{Nb}_{2} \mathrm{O}_{5}$ nanoparticles synthesized via a surfactant-modified sol-gel process. Mater. Lett. 2012, 78, 135-138. [CrossRef]

28. Liu, J.; Zhang, T.; Wang, Z.; Dawson, G.; Chen, W. Simple pyrolysis of urea into graphitic carbon nitride with recyclable adsorption and photocatalytic activity. J. Mater. Chem. 2011, 21, 14398. [CrossRef]

29. Greenwood, N.N.; Earnshaw, A. Chemistry of the Elements, 2nd ed; Butterworth-Heinemann: Oxford, UK, 1998.

30. Yamashita, H.; Harada, M.; Misaka, J.; Takeuchi, M.; Neppolian, B.; Anpo, M. Photocatalytic degradation of organic compounds diluted in water using visible light-responsive metal ion-implanted $\mathrm{TiO}_{2}$ catalysts: Fe ion-implanted $\mathrm{TiO}_{2}$. Catal. Today 2003, 84, 191-196. [CrossRef]

31. Malengreaux, C.M.; Pirard, S.L.; Léonard, G.; Mahy, J.G.; Klobes, B.; Herlitschke, M.; Hermann, R.; Heinrichs, B.; Bartlett, J.R. Study of the photocatalytic activity of $\mathrm{Fe}^{3+}, \mathrm{Cr}^{3+}, \mathrm{La}^{3+}$ and $\mathrm{Eu}^{3+}$ single- doped and co-doped $\mathrm{TiO}_{2}$ catalysts produced by aqueous sol-gel processing. J. Alloys Compd. 2017, 691, 726-738. [CrossRef]

32. Yoshimura, K.; Miki, T.; Iwama, S.; Tanemura, S. Characterization of niobium oxide electrochromic thin films prepared by reactive d.c. magnetron sputtering. Thin Solid Films 1996, 281-282, 235-238. [CrossRef]

33. Weibin, Z.; Weidong, W.; Xueming, W.; Xinlu, C.; Dawei, Y.; Changle, S.; Li, B. The investigation of $\mathrm{NbO}_{2}$ and $\mathrm{Nb}_{2} \mathrm{O}_{5}$ electronic structure by XPS, UPS and first principles methods. Surf. Interface Anal. 2013, 45, 1206-1210. [CrossRef]

34. Scheidt, G. Caracterização óptica de filmes finos de $\mathrm{NbO}_{x}$ obtidos por sputtering reativo. Master's Degree in Nuclear Technology-Materials-Nuclear and Energy Research Institute, University of São Paulo, São Paulo, Brazil, 2014.

35. Hamaguchi, R. Preparação, caracterização e estudo das propriedades fotocatalíticas de catalisadores obtidos de dopagem de $\mathrm{TiO}_{2}$ e $\mathrm{Nb}_{2} \mathrm{O}_{5}$. Master's Degree, DQ-FFCLRP-USP, Ribeirão Preto, Brazil, 2011.

36. Prado, A.G.S.; Bolzon, L.B.; Pedroso, C.P.; Moura, A.O.; Costa, L.L. $\mathrm{Nb}_{2} \mathrm{O}_{5}$ as efficient and recyclable photocatalyst for indigo carmine degradation. Appl. Catal. B 2008, 82, 219-224. [CrossRef]

37. Gallo, I.F.L. Preparação e caracterização de fotocatalisadores heterogêneos de titânio e nióbio e avaliação do potencial de fotodegradação. Master's Degree, FFCL-USP, Ribeirão Preto, Brazil, 2016.

38. Dalponte, I.; Mathias, A.L.; Jorge, R.M.M.; Weinschutz, R. Degradação fotocatalítica de tartrazina com $\mathrm{TiO}_{2}$ imobilizado em esferas de alginato. Quim. Nova. 2016, 39, 1165-1169. [CrossRef]

39. Kosera, V.S.; Cruz, T.M.; Chaves, E.S.; Tiburtius, E.R.L. Triclosan degradation by heterogeneous photocatalysis using ZnO immobilized in biopolymer as catalyst. J. Photochem. Photobiol. 2017, 344, 184-191. [CrossRef] 
40. Son, H.-S.; Lee, S.-J.; Cho, I.-H.; Zoh, K.-D. Kinetics and mechanism of TNT degradation in $\mathrm{TiO}_{2}$ photocatalysis. Chemosphere 2004, 57, 309-317. [CrossRef]

41. Lenzi, G.G.; Fávero, C.V.B.; Colpini, L.M.S.; Bernabe, H.; Baesso, M.L.; Specchia, S.; Santos, O.A.A. Photocatalytic reduction of $\mathrm{Hg}(\mathrm{II})$ on $\mathrm{TiO}_{2}$ and $\mathrm{Ag} / \mathrm{TiO}_{2}$ prepared by the sol-gel and impregnation methods. Desalination 2011, 270, 241-247. [CrossRef] 